\title{
Ideas for Creation: A Comparison of the Learning Results of Three-Dimensional Images between Active Learning and Child-Centered Education of Product Design Students
}

\author{
https://doi.org/10.3991/ijet.v16i11.21597 \\ Songwut Egwutvongsa ${ }^{(凶)}$, Somchai Seviset \\ King Mongkut's Institute of Technology Ladkrabang, Bangkok, Thailand \\ Songwut.aedkmitl.ac.th
}

\begin{abstract}
This research conducted a comparison of the learning results for the creation of three-dimensional images between active learning and childcentered education. The population and group sampling comprised 90 freshmen students in the Design Education program of King Mongkut's Institute of Technology Ladkrabang during the Academic Year 2019-2020. Similarly, the population was classified from the selection of systematic random sampling with 45 people for active learning and 45 people for child-centered education. In addition, the research tool used in this research was knowledge and skills test for the students, which was an appropriate test with the simplicity and ability to categorize, accordingly $(\mathrm{P}=.64 ; \mathrm{r}=.62)$. The results showed that the students who were studying active learning had higher scores than those studying childcentered education, which had a statistical significance of .05. This case brought the positive features of each of the two methods to be integrated as mixed learning that would also be suitable for the study program of the students. As a result, it was found that the pretest and t post-test had a correlation (Sig. $=0.000)$ in a positive direction $(\mathrm{r}=0.492)$, as well as displayed the post-test scores at a higher level than the pretest scores, thus having a statistical significance level of .05 .
\end{abstract}

Keywords-Idea, three-dimensional images, active learning, child-centered education, product design

\section{Introduction}

The learning process in the twenty-first century is significantly being integrated with the teaching pattern through a variety of tools and teaching media [1]. As a consequence, this has become relevant for the transferring characteristic of knowledge to stimulate students to be interested in learning through intelligence [2]. Therefore, designed learning is essential for developing the learning patterns that could conform to the ever-changing world in the twenty-first century without creating only the students' own knowledge. 
However, from the knowledge of modern product design students, this should promote the students to have their own thoughts and imagination through active learning in terms of enhancing their intelligence with real action processes [3]. Thus, this would direct the knowledge into the learners with effectiveness by using active learning and child-centered education. In contrast, these methods have clearly gained their own specificness with regard to the learning processes, strengths, and weaknesses in varying levels [4]. As such, each learning process was compared to the copoints on the same core, which are also called the aiming goal to assist the learners to gain knowledge from the action or real performance with effectiveness. As a result, this has become the learning characteristic for the promotion of having the analytical skills and imagination for learners.

Furthermore, the learning processes from active learning and child-centered education could be applied with the designed learning. In this case, this would not only depend on textbooks, but also involve the intellectual knowledge from students' own analysis causing their cognitive knowledge processes to gain the highest level of effectiveness [5]. Similarly, this would also assist the students to utilize the knowledge from active learning to be applied with the creative designing of three-dimensional images as widespread products, including promoting the creative ideas for learners at a broader level [6].

\section{Materials and Methods}

\section{$2.1 \quad$ Objective}

To conduct a comparison of the learning results in designing three-dimensional images from product design students by using both active learning and child-centered education.

\section{$2.2 \quad$ Scope}

1. The population comprised 90 freshmen students in the Design Education program of the Department of Architectural Education and Design, Faculty of Industrial Education and Technology, King Mongkut's Institute of Technology Ladkrabang during the Academic Year 2019-2020.

2. The above-mentioned group sampling was classified into two groups consisting of 45 people each. The selection method used the group sampling of systematic random sampling.

The research tool was the test of the principle of three-dimensional imaging that had five subjects. The two groups used the learning procedure methods of active learning and child-centered education. 
Table 1. Quality assessment test to measure the learning results by creating three-dimensional images

\begin{tabular}{|l|c|c|c|c|}
\hline \multicolumn{1}{|c|}{ Test Subject } & $\mathrm{P}$ & $\mathrm{r}$ & $\begin{array}{c}\text { Quality Assessment Test } \\
\text { from Value P and Value r }\end{array}$ & Test Attribution \\
\hline 1 Imagination & .54 & .90 & Good & Suitable difficulty and easy classification. \\
\hline 2 Beauty & .70 & .45 & Good & Suitable difficulty and easy classification. \\
\hline 3 Eyesight view & .73 & .42 & Good & Suitable difficulty and easy classification. \\
\hline 4 illusion & .51 & .94 & Good & Suitable difficulty and easy classification. \\
\hline 5 Theory Principle & .74 & .47 & Good & Suitable difficulty and easy classification. \\
\hline Total & .64 & .62 & Good & $\begin{array}{c}\text { Rather suitable difficulty and rather easy } \\
\text { classification. }\end{array}$ \\
\hline
\end{tabular}

From the test, it was found that the value of Discrimination: P was able to be categorized easily as being an appropriate test as well as the part of the Difficulty: $r$ in the test was also easy for making the scores to receive a good classification $(\mathrm{P}=.64 ; \mathrm{r}=$ $.62)$.

Data analysis: This demonstrated the mean, standard deviation (S.D.), and independent t-test for making the comparison about the learning results between the two group samplings.

Research design: This research focused on the study of the results under the title of the principle of three-dimensional imaging (3D) for the two groups with the differences in the teaching methods between active learning and child-centered education, and this was able to make a comparison between the two teaching methods for searching their suitability by creating knowledge of the above-mentioned principle for the freshmen students in the Design Education program.

\subsection{Research framework}

Table 2. Working framework

\begin{tabular}{|c|c|}
\hline $\begin{array}{l}\quad \text { Child-center ed learning [7] } \\
\text { Cultivation to acquire knowledge by oneself. } \\
\text { Creating learning skills by oneself through multiple } \\
\text { channels } \\
>\text { Stimulation to havelearning activities by oneself. }\end{array}$ & $\begin{array}{l}\text { Assessment Result from Learning [8] } \\
>\text { Focusing on correctness and validity. } \\
>\text { Having modernness for the assessment lists to } \\
\text { be tested. } \\
>\text { Showing the credit of each origin to transfer } \\
\text { knowledge conforming with the objective on the } \\
\text { expected learning. }\end{array}$ \\
\hline $\begin{array}{l}\text { Active Learning [9] } \\
\text { performance. } \\
\text { perimulation to have active learning with one's own } \\
\text { Stimulation to have the effort to make success. } \\
\text { Acknowledging multiple channels for each person. } \\
>\text { Transforming from learners into cocreators. }\end{array}$ & $\begin{array}{l}\text { Learning Objective by Focusing on Creation } \\
\text { [i ] ] } \\
>\text { Differences of experience with the effected } \\
\text { chances to the learning results for human beings. }\end{array}$ \\
\hline $\begin{array}{l}\text { Learning to stimulate having creative ideas based on } \\
\text { the differences for each person to make intelligence. }\end{array}$ & \\
\hline
\end{tabular}




\section{Results}

The active learning step of the student groups was based on the tools; such as, textbooks, exercises in and outside the classroom, including the promotion of creative thinking activities, knowledge test after learning in the classroom, and other related aspects (Tables 3 and 4).

Table 3. Activities in the classroom according to the concepts of the active learning procedure.

\begin{tabular}{|c|c|c|c|}
\hline \multirow{2}{*}{$\begin{array}{c}\text { Activities in the } \\
\text { Classroom }\end{array}$} & \multirow{2}{*}{ Needed Goal } & \multicolumn{2}{|c|}{ Promoting Activities } \\
\hline & & Intelligence & Skill \\
\hline \multirow[t]{2}{*}{$\begin{array}{l}\text { 1. Learning the con- } \\
\text { tents of the lessons and } \\
\text { knowledge creation of } \\
\text { the theories. }\end{array}$} & $\begin{array}{l}\text { Relevant knowledge } \\
\text { of the theory with the } \\
\text { three-dimensional } \\
\text { images from stimulated } \\
\text { learning between in- } \\
\text { structors and learners } \\
\text { to respond by asking } \\
\text { and answering ques- } \\
\text { tions [11]. }\end{array}$ & $\sqrt{ }$ & \\
\hline & $\begin{array}{l}\text { Broad knowledge } \\
\text { with a variety of inte- } \\
\text { grated knowledge to } \\
\text { develop multiple } \\
\text { knowledge [12-13]. }\end{array}$ & $\checkmark$ & \\
\hline \multirow[t]{2}{*}{$\begin{array}{l}\text { 2. Practicing work } \\
\text { from presenting their } \\
\text { own ideas. }\end{array}$} & $\begin{array}{l}\text { Students joined } \\
\text { groups and presented } \\
\text { their opinions by } \\
\text { brainstorming to solve } \\
\text { the problematic ques- } \\
\text { tions and answering } \\
\text { with creative ideas [14- } \\
\text { 15]. }\end{array}$ & $\sqrt{ }$ & $\sqrt{ }$ \\
\hline & $\begin{array}{l}\text { Criticizing the ideas } \\
\text { from friends' groups to } \\
\text { present creative ideas } \\
\text { through the beauty and } \\
\text { new aspects of three- } \\
\text { dimensional images } \\
\text { [16-17]. }\end{array}$ & $\sqrt{ }$ & $\sqrt{ }$ \\
\hline \multirow[t]{2}{*}{$\begin{array}{l}\text { 3. Practicing designing } \\
\text { and creating three- } \\
\text { dimensional images } \\
\text { with the principles and } \\
\text { concepts. }\end{array}$} & $\begin{array}{l}\text { Writing about the } \\
\text { images to present } \\
\text { thoughts and joining to } \\
\text { express opinions about } \\
\text { other students' work }\end{array}$ & & $\checkmark$ \\
\hline & $\begin{array}{l}\text { [18]. } \\
\text { Practicing the writ- } \\
\text { ing skills about the } \\
\text { three-dimensional } \\
\text { images as the concept } \\
\text { to gain drafting writing } \\
\text { skills and writing about } \\
\text { images for communi- } \\
\text { cating to other people } \\
\text { [19]. }\end{array}$ & & $\checkmark$ \\
\hline
\end{tabular}




\begin{tabular}{|c|c|c|c|}
\hline & $\begin{array}{l}>\text { Learning with intel- } \\
\text { lectual integration into } \\
\text { in-depth skills through } \\
\text { active learning from } \\
\text { memorizing with effec- } \\
\text { tiveness. }\end{array}$ & $\checkmark$ & $\sqrt{ }$ \\
\hline \multirow[t]{3}{*}{$\begin{array}{l}\text { 4. Practicing to pro- } \\
\text { duce models from the } \\
\text { concepts through ac- } \\
\text { tive learning. }\end{array}$} & $\begin{array}{l}\text { Learning by manu- } \\
\text { facturing a model with } \\
\text { a three-dimensional } \\
\text { attribute to be ready for } \\
\text { working. }\end{array}$ & & $\sqrt{ }$ \\
\hline & $\begin{array}{l}>\text { Designing the com- } \\
\text { municative concept } \\
\text { through the presenta- } \\
\text { tion of the methods of } \\
\text { the product model } \\
\text { from the intellectual } \\
\text { process with special } \\
\text { intelligence [18]. }\end{array}$ & $\checkmark$ & \\
\hline & $\begin{array}{l}\text { Connection of intel- } \\
\text { ligence from the ex- } \\
\text { pression of active } \\
\text { learning [20]. }\end{array}$ & $\checkmark$ & $\checkmark$ \\
\hline \multirow[t]{2}{*}{$\begin{array}{l}\text { 5. Bringing creative } \\
\text { work to be applied } \\
\text { with the requirements } \\
\text { of the communities and } \\
\text { local areas. }\end{array}$} & $\begin{array}{l}\text { Result of the presen- } \\
\text { tation from the } \\
\text { thoughts of active } \\
\text { learning by the re- } \\
\text { quired learners reflect- } \\
\text { ing about applying } \\
\text { their thoughts with an } \\
\text { improved design. }\end{array}$ & $\checkmark$ & \\
\hline & $\begin{array}{l}\text { Eagerness from the } \\
\text { feeling of learning to } \\
\text { improve the thinking, } \\
\text { designing, and agree- } \\
\text { ment methods as sig- } \\
\text { nificant and high flexi- } \\
\text { ble skills of the twenty- } \\
\text { first century [21-22]. }\end{array}$ & $\checkmark$ & $\sqrt{ }$ \\
\hline
\end{tabular}

From the learning atmosphere of active learning in the classroom, it was found that the students had high concentration in the contents of the lesson of the creation of three-dimensional images from the instructors. Thus, this resulted in the students fully understanding the relevant principles of the theory with the objectives of the units' lesson. Similarly, as a consequence of the active learning skill, the students were able to make the performance have a positive result from the teaching to gain a positive level. In contrast, from the creative concepts from the students' work, this showed the performance at a lesser level with the learning and performance in terms of the instructor's presentation in the classroom. Therefore, this appeared as a framework with a high level of effective creativity, except for affecting thinking outside the box to begin the new creative idea differently from the teaching at a lesser level. In this case, 
it was congruent to the structure of the active learning teaching patterns that demonstrated the negative effects of the creative skills as the requirements of intellectual independence from the learners with significant roles.

Table 4. Activities in the classroom as a learning procedure framework of child-centered learning.

\begin{tabular}{|c|c|c|c|}
\hline \multirow{2}{*}{$\begin{array}{r}\text { Activity in the } \\
\text { Classrooms }\end{array}$} & \multirow[t]{2}{*}{ Required Goal } & \multicolumn{2}{|c|}{ Promoting Activities } \\
\hline & & Intelligence & Skill \\
\hline \multirow{2}{*}{$\begin{array}{l}\text { 1. Instructors guided } \\
\text { the problems for } \\
\text { stimulation. }\end{array}$} & $\begin{array}{l}\text { Stimulation for seeing the importance of } \\
\text { the three-dimensional images and theo- } \\
\text { ry principle based on questioning with } \\
\text { the requirements for additional learning } \\
\text { stimulation [23]. }\end{array}$ & $\checkmark$ & \\
\hline & $\begin{array}{l}\text { The students draw the intellectual drafts } \\
\text { about problems with the creation of } \\
\text { three-dimensional images in design } \\
\text { [24]. }\end{array}$ & $\checkmark$ & $\checkmark$ \\
\hline \multirow{2}{*}{$\begin{array}{l}\text { 2. Presenting the gath- } \\
\text { ered results from } \\
\text { mapping. }\end{array}$} & $\begin{array}{l}\text { The students presented the gathered } \\
\text { results with their classmates to under- } \\
\text { stand and learn new things about differ- } \\
\text { ent issues. }\end{array}$ & $\checkmark$ & \\
\hline & $\begin{array}{l}\text { Criticizing classmates' ideas widely and } \\
\text { concluding the issues suitably with } \\
\text { flexible thinking skills in creative ideas } \\
\text { with beauty and view creation issues as } \\
\text { the main part [25]. }\end{array}$ & $\checkmark$ & $\checkmark$ \\
\hline \multirow{3}{*}{$\begin{array}{l}\text { 3. Designing activities } \\
\text { with three- } \\
\text { dimensional images } \\
\text { as principles and } \\
\text { concepts [26]. }\end{array}$} & $\begin{array}{l}\text { Creating three-dimensional images } \\
\text { activities based on classmates' partici- } \\
\text { pation to exchange the creative skills } \\
\text { together [27]. }\end{array}$ & $\checkmark$ & $\checkmark$ \\
\hline & $\begin{array}{l}\text { Learning designing skills and practicing } \\
\text { writing skills of the three-dimensional } \\
\text { images gained from classmates by ex- } \\
\text { changing ideas and skills [19]. }\end{array}$ & & $\checkmark$ \\
\hline & $\begin{array}{l}\text { Learning with intellectual integration } \\
\text { into the learning skills to gain effective } \\
\text { memories. }\end{array}$ & $\checkmark$ & \\
\hline \multirow{2}{*}{$\begin{array}{l}\text { 4. Practicing the crea- } \\
\text { tion of the model as } \\
\text { a concrete design } \\
\text { [28]. }\end{array}$} & $\begin{array}{l}\text { Gathering for the modeling of students' } \\
\text { productions to fulfill the thoughts } \\
\text { among classmates. }\end{array}$ & & $\checkmark$ \\
\hline & $\begin{array}{l}\text { Representing ideas by beginning to take } \\
\text { action in factories for stimulation to } \\
\text { transfer thoughts and craft skills [29]. }\end{array}$ & $\sqrt{ }$ & \\
\hline
\end{tabular}




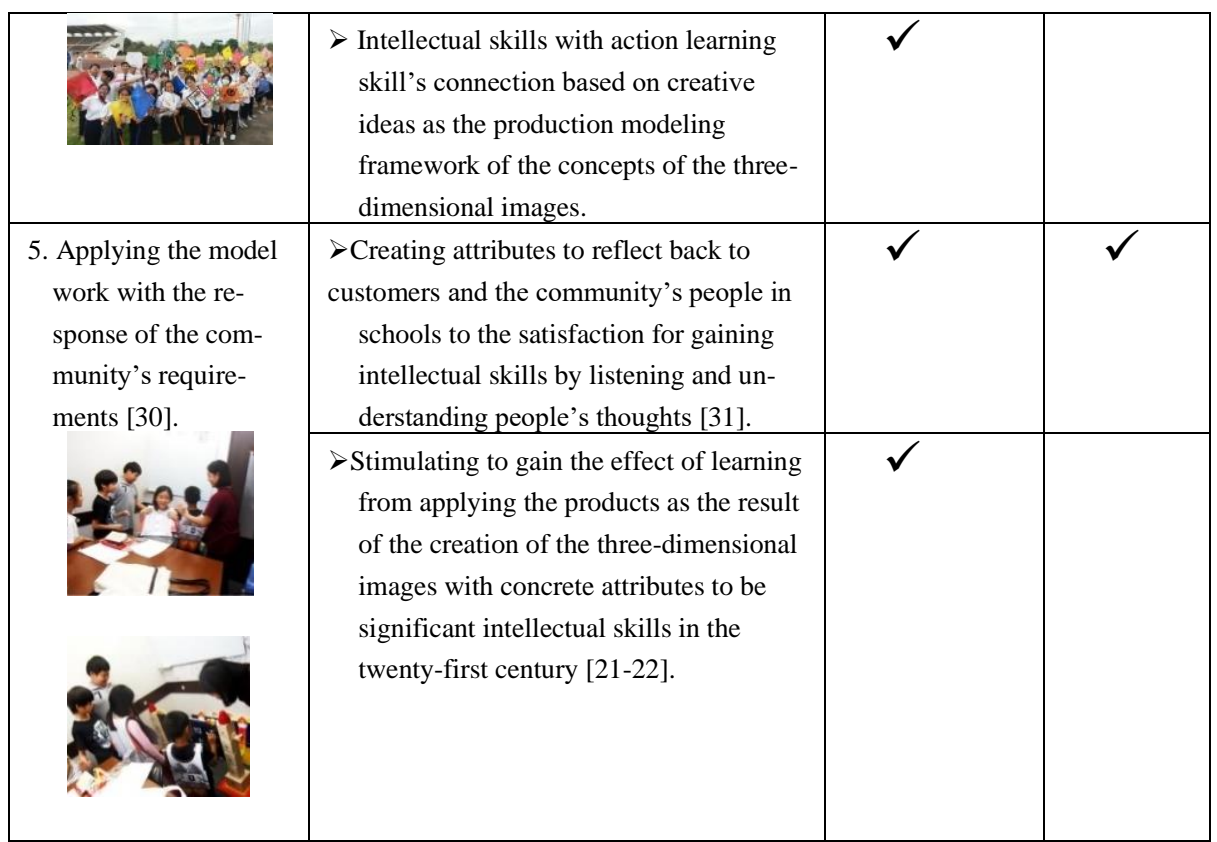

From the learning atmosphere of the learning procedures of child-centered learning, it was found that the students had the activeness to join in expressing the involved knowledge of the concepts as thought mapping in different levels. Thus, this resulted in different learning requirements for the creation of the three-dimensional images to exchange the knowledge of the students in the classroom. With this case, this involved a creative idea at a high level, except for gaining the perfection of the threedimensional masterpieces at a lesser level due to the excessive method of the students. Then, there were some creative methods of the students that were not successful in the production step that was congruent to the learning concept with the aim of the result at a high level for creative ideas. As a result, this had a lesser opportunity to be accomplished with the increasing of the creative ideas [32].

Moreover, the test procedure was involved with the knowledge creation method from the creative idea of using three-dimensional images for the students. In this case, this showed the relevance of the ideas relating to the intellectual skills and action learning skills with a different result [33-34]. Similarly, according to the creative thought levels from the intellectual skills, this presented the different levels of the expression of the students' behavior in the classroom and the effects of the successful trend as the unit learning goals (Table 5). 
Table 5. Comparison of the result of students' satisfaction after the learning test in the classroom with active learning and child-centered learning $(n=45)$.

\begin{tabular}{|l|c|c|c|c|c|c|}
\hline \multicolumn{1}{|c|}{ Specific Assessment List } & \multicolumn{2}{|c|}{ Active Learning } & \multicolumn{2}{c|}{$\begin{array}{c}\text { Child-centered } \\
\text { Learning }\end{array}$} & \multicolumn{2}{c|}{ Comparison } \\
\cline { 2 - 7 } & Mean & S.D. & Mean & S.D. & \multicolumn{1}{c|}{ Sig. } \\
\hline $\begin{array}{l}\text { 1. Learning conditions in the class- } \\
\text { room; tidiness; classroom control; } \\
\text { concentration. }\end{array}$ & 4.69 & 0.47 & 4.24 & 0.65 & $3.740^{*}$ & 0.000 \\
\hline $\begin{array}{l}\text { 2. Increasing of intellectual skills or } \\
\text { availability of effective knowledge. }\end{array}$ & 4.27 & 0.65 & 4.04 & 0.67 & 1.589 & 0.058 \\
\hline $\begin{array}{l}\text { 3. Modeling of active learning skills } \\
\text { and writing of the creative three- } \\
\text { dimensional images. }\end{array}$ & 4.13 & 0.66 & 4.18 & 0.65 & -0.322 & 0.374 \\
\hline $\begin{array}{l}\text { 4. Feeling confident in gaining intel- } \\
\text { lectual knowledge with action learn- } \\
\text { ing skills in the classroom. }\end{array}$ & 4.20 & 0.66 & 3.56 & 0.72 & $4.409 *$ & 0.000 \\
\hline 5. Feeling fun in learning. & 3.87 & 0.69 & 4.56 & 0.50 & -5.393 & 0.000 \\
\hline $\begin{array}{l}\text { 6. Having independent feelings with } \\
\text { independent learning. }\end{array}$ & 4.36 & 0.57 & 4.31 & 0.60 & 0.361 & 0.359 \\
\hline Total & $\mathbf{4 . 3 1}$ & $\mathbf{0 . 6 6}$ & $\mathbf{4 . 1 6}$ & $\mathbf{0 . 6 9}$ & $\mathbf{2 . 8 3 1 *}$ & $\mathbf{0 . 0 0 2}$ \\
\hline
\end{tabular}

* This was different with a statistical significance level of .05.

a) From the learning conditions in the classroom and the feeling of confidence in the classroom, it was found that active learning in the classroom had the mean of satisfaction for the students at a higher level than that of child-centered learning with a statistical significance level of .05 .

b) From the increasing of intellectual skills and independent learning, it was found that active learning in the classroom had the mean of satisfaction for the students at a higher level than that of child-centered learning with a statistical significance level of .05 .

c) From the increasing of the performance skills, it was found that child-centered learning in the classroom had the mean of satisfaction for the students at a higher level than that of active learning with a statistical significance level of .05.

d) From the amusement for learning, it was found that child-centered learning in the classroom had the mean of satisfaction for the students at a higher level than that of active learning with a statistical significance level of .05.

Hence, from the comparison of the students' satisfaction to the two learning procedures, it could be concluded that active learning in the classroom had the mean of students' satisfaction at a higher level than child-centered learning with a statistical significance level of .05. 
Table 6. Test result of the students' intellectual skills and active learning skills ( $\mathrm{n}=45)$.

\begin{tabular}{|c|c|c|c|c|c|c|}
\hline \multirow[t]{2}{*}{$\begin{array}{c}\text { Specific Assessment List } \\
\text { (Assessment Scores with Each of 50) }\end{array}$} & \multicolumn{2}{|c|}{ Active Learning } & \multicolumn{2}{|c|}{$\begin{array}{c}\text { Child-centered } \\
\text { Learning }\end{array}$} & \multicolumn{2}{|c|}{ Comparison } \\
\hline & Mean & S.D. & Mean & S.D. & $t$ & Sig. \\
\hline 1. Imagination with intellectual promotion. & 38.91 & 3.66 & 41.72 & 3.28 & $-3.835^{*}$ & 0.000 \\
\hline 2. Beauty from practicing skills. & 42.21 & 3.31 & 33.63 & 6.58 & $7.817^{*}$ & 0.000 \\
\hline 3. Suitable eye views. & 41.98 & 4.54 & 31.65 & 5.69 & $9.518^{*}$ & 0.000 \\
\hline 4. Suitable illusion. & 35.37 & 6.88 & 32.76 & 7.61 & $1.707 *$ & 0.046 \\
\hline 5. Theory principle about knowledge. & 42.47 & 3.49 & 30.12 & 6.27 & $\begin{array}{c}11.543 \\
*\end{array}$ & 0.000 \\
\hline Total & 40.49 & 5.21 & 33.59 & 7.05 & $\begin{array}{c}12.923 \\
*\end{array}$ & 0.000 \\
\hline
\end{tabular}

* This was different with a statistical significance level of .05.

From the testing scores to promote the intellectual skills of the creation of threedimensional images, it was found that the students undertaking child-centered learning had test scores at a higher level than the students undertaking active learning with a statistical significance level of .05 .

From the testing scores of the beauty from practicing skills, the suitable eye view, the suitable illusion, and the theory principle about knowledge of the four fields, it was found that the students undertaking active learning had higher scores than the students undertaking child-centered learning with a statistical significance level of .05 .

In conclusion, according to the overall test results of the creation of threedimensional images, it was found that the students undertaking active learning had a mean score of 40.49, and the students undertaking child-centered learning had a mean score of 33.59. Thus, this presented that the results of learning with active learning had a higher level than learning with child-centered learning with a statistical significance level of .05 .

3.2 The concluding step of the direction of the suitable learning pattern with the learning unit of the creation of the three-dimensional images of the students was based on the test of these teaching methods that contributed to the result for the learning pattern's creation with the integration of positive features. Then, it was introduced into the learning pattern with the student groups (Table 7). 
Paper-Ideas for Creation: A Comparison of the Learning Results of Three-Dimensional Images..

Table 7. Integration with the learning procedure's planning in the classroom as a new pattern of the creation of three-dimensional images.

\begin{tabular}{|c|c|c|c|c|}
\hline $\begin{array}{l}\text { Component in the Learning Unit } \\
\text { of the Creation of the Three- } \\
\text { dimensional Images }\end{array}$ & 言 & 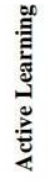 & 竞 & $\begin{array}{l}\text { New Learning Pattern Integration } \\
\text { (Integration for the positive points of active } \\
\text { learning and child-centered learning with a suitable } \\
\text { learning pattern as per the students' requirements } \\
\text { in the classroom.) }\end{array}$ \\
\hline $\begin{array}{l}\text { 1. Imagination: Intellectual } \\
\text { independent promotion into broad } \\
\text { creation. }\end{array}$ & $\begin{array}{l}\stackrel{\vec{J}}{00} \\
\vec{\Xi} \\
\stackrel{E}{E}\end{array}$ & & & $\begin{array}{l}\text { Applied during the learning with the } \\
\text { requirements by allowing independence with the } \\
\text { expressed stimulation for designing the creation } \\
\text { without closing ideas. }\end{array}$ \\
\hline $\begin{array}{l}\text { 2. Beauty: Practicing writing } \\
\text { communication skills with three- } \\
\text { dimensional images. }\end{array}$ & है & & & $\begin{array}{l}\text { Applied during the craft learning by emphasizing } \\
\text { practicing and action learning by letting students } \\
\text { do exercises with planning and taking action } \\
\text { with the objectives. }\end{array}$ \\
\hline 3. Suitable eye view. & 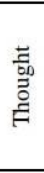 & & & $\begin{array}{l}\text { Applied during the learning as relevant ideas and } \\
\text { theories about the suitability between the eye } \\
\text { view and beauty. } \\
\text { Applied with an explanation about the learning } \\
\text { to guide the action learning to gain a positive } \\
\text { result. }\end{array}$ \\
\hline 4. Suitable illusion images. & Uี & & & $\begin{array}{l}\text { Applied during action learning from the students } \\
\text { to gain a positive result. } \\
\text { Determined to examine if the students applied } \\
\text { active learning with the design. }\end{array}$ \\
\hline 5. Knowledge principle and theory. & $\begin{array}{l}\stackrel{\overrightarrow{0}}{00} \\
\vec{\Xi} \\
\stackrel{E}{E}\end{array}$ & & & $\begin{array}{l}\text { Applied for the learning of the relevant theories } \\
\text { about the creation of the three-dimensional } \\
\text { images emphasizing knowledge and memory } \\
\text { learning. } \\
\text { Determined the main contents by the instructors } \\
\text { and presented to the learners for other } \\
\text { knowledge issues. }\end{array}$ \\
\hline $\begin{array}{l}\text { 6. Learning atmosphere in the } \\
\text { classroom with the goal to } \\
\text { develop concentration in the } \\
\text { classroom. }\end{array}$ & 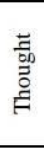 & & & $\begin{array}{l}\text { Applied for the classroom management patterns } \\
\text { by the instructors to develop the core knowledge } \\
\text { and give an opportunity for the learners to } \\
\text { express ideas with the objectives of the learning } \\
\text { content. }\end{array}$ \\
\hline $\begin{array}{l}\text { 7. Intellectual field to be available } \\
\text { with high effective knowledge. }\end{array}$ & 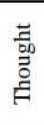 & & & $\begin{array}{l}\text { Stimulated to gain the intellectual skills as } \\
\text { memory patterns from the origins and ideas of } \\
\text { the thinkers and the international creators } \\
\text { assessed by the test in the classrooms. }\end{array}$ \\
\hline $\begin{array}{l}\text { 8. Active learning skills from the } \\
\text { models and writing of the creative } \\
\text { three-dimensional images. }\end{array}$ & हुँ & & & $\begin{array}{l}\text { Stimulated learning based on child-centered } \\
\text { learning with different requirement skills in each } \\
\text { field planned with the creative concepts for each } \\
\text { learner. }\end{array}$ \\
\hline $\begin{array}{l}\text { 9. Have a feeling of confidence with } \\
\text { the knowledge in the classroom. }\end{array}$ & $\begin{array}{l}\stackrel{\overrightarrow{0}}{00} \\
\stackrel{\Xi}{0} \\
E\end{array}$ & & & $\begin{array}{l}\text { Stimulated seeing the importance of knowledge } \\
\text { as being a positive result after learning in and } \\
\text { outside the classrooms by aiming at generating a } \\
\text { feeling of confidence. }\end{array}$ \\
\hline $\begin{array}{l}\text { 10. Have a feeling of amusement } \\
\text { with learning. }\end{array}$ & 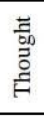 & & & $\begin{array}{l}\text { Created positive attitudes in the classroom by } \\
\text { stimulating views of creative concepts with } \\
\text { effectiveness; creative concepts were created on } \\
\text { the basis of happiness. }\end{array}$ \\
\hline $\begin{array}{l}\text { 11. Have a feeling of independence } \\
\text { and independent learning. }\end{array}$ & 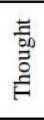 & & & $\begin{array}{l}\text { Stimulated having continuous questions from } \\
\text { the learning in the classrooms by leveling up } \\
\text { the intellectual skills; independence was created } \\
\text { from the questioning as the new main points. }\end{array}$ \\
\hline
\end{tabular}


The learning of active learning was integrated with the new learning issues as follows: 1) Beauty by focusing on practicing communication skills with images, 2) suitable eye view, 3) suitable illusion images, 4) knowledge principles and theories, 5) learning atmosphere in the classroom, 6) intellectual field to be available for high effective knowledge, 7) feeling of confidence on the knowledge in the classroom, and 8) feeling of independence and independent learning and other fields. With this case, according to all the above positive fields, this presented that the learning of active learning responded to the creation of the three-dimensional images for the students by being promoted with the active learning skills as high effectiveness.

In this case, the learning of child-centered learning was integrated with the new learning patterns as follows: 1) Imagination, 2) active learning skills of the creative models, 3) feeling of fun with learning and other fields. Then, according to the above positive fields, this presented that the learning of child-centered learning enabled a response with the creation of the three-dimensional images for the students by being promoted with the creative idea processes with high effectiveness.

Therefore, this enabled the integration of the learning patterns with the positive points of active learning and child-centered learning by applying them with the experiment groups, including modeling with the new developed learning conditions to examine the suitability of the new integrated learning patterns (Table 8).

Table 8. Learning assessment result and active learning with the new developed integration $(n=45)$.

\begin{tabular}{|l|c|c|c|c|c|c|c|c|}
\hline $\begin{array}{c}\text { Specific As- } \\
\text { sessment List } \\
\begin{array}{c}\text { Assessment } \\
\text { Scores for } \\
\text { Each of 50) }\end{array}\end{array}$ & \multicolumn{2}{|c|}{ Pretest } & \multicolumn{2}{c|}{ Post-test } & \multicolumn{2}{c|}{$\begin{array}{c}\text { Comparison of } \\
\text { Pretest } \\
\text { Pond }\end{array}$} & \multicolumn{2}{c|}{ Paired Samples } \\
\cline { 2 - 8 } & & S.D. & Mean & S.D. & $t$ & \multicolumn{2}{c|}{ Sig. } & \multicolumn{2}{c|}{ Correlation } & Sig. \\
\hline $\begin{array}{l}\text { 1. Imagination } \\
\text { and creative } \\
\text { ideas. }\end{array}$ & 27.56 & 5.827 & 38.17 & 6.820 & $15.878^{*}$ & 0.000 & 0.760 & 0.00 \\
\hline $\begin{array}{l}\text { 2. Beauty and } \\
\text { stimulation of } \\
\text { interests. }\end{array}$ & 29.02 & 5.545 & 36.89 & 6.444 & $9.928^{*}$ & 0.000 & 0.615 & 0.00 \\
\hline $\begin{array}{l}\text { 3. Suitable eye } \\
\text { view. }\end{array}$ & 23.96 & 7.202 & 28.33 & 8.943 & $6.228^{*}$ & 0.000 & 0.852 & 0.00 \\
\hline $\begin{array}{l}\text { 4. Suitable } \\
\text { illusion imag- } \\
\text { es. }\end{array}$ & 25.92 & 6.181 & 36.10 & 5.841 & $11.204^{*}$ & 0.000 & 0.486 & 0.00 \\
\hline $\begin{array}{l}\text { 5. Principles } \\
\text { and theories of } \\
\text { the contents }\end{array}$ & 20.96 & 3.347 & 40.44 & 3.788 & $25.046^{*}$ & 0.000 & -0.066 & 0.66 \\
\hline \begin{tabular}{l} 
Totals \\
\hline
\end{tabular} & $\mathbf{2 5 . 4 8}$ & $\mathbf{6 . 3 7 1}$ & $\mathbf{3 5 . 9 9}$ & $\mathbf{7 . 7 0 9}$ & $\mathbf{2 1 . 9 1 6 *}$ & $\mathbf{0 . 0 0 0}$ & $\mathbf{0 . 4 9 2}$ & $\begin{array}{c}\mathbf{0 . 0 0} \\
\mathbf{0}\end{array}$ \\
\hline
\end{tabular}

* This was different with a statistical significance level of .05 .

From the imagination and the creative ideas, it was found that the pretest and the post-test were correlated with each other $(\mathrm{Sig} .=0.000)$, as the positive values had the same direction of correlation $(\mathrm{r}=0.760)$, and the post-test scores had a higher level than the pretest with a statistical significance level of .05. 
From the beauty and the stimulation of interests, it was found that the pretest and the post-test were correlated with each other (Sig. $=0.000)$, as the positive values had the same direction of correlation $(r=0.760)$, and the post-test scores had a higher level than the pretest with a statistical significance level of .05 .

From the suitable eye view, it was found that the pretest and the post-test were correlated with each other $($ Sig. $=0.000)$, as the positive values had the same direction of correlation $(\mathrm{r}=0.760)$, and the post-test scores had a higher level than the pretest with a statistical significance level of .05 .

From the suitable illusion images, it was found that the pretest and the post-test were correlated with each other (Sig. $=0.000)$ as the positive values had the same direction of correlation $(r=0.760)$, and the post-test scores had a higher level than the pretest with a statistical significance level of .05 .

From the principles and theory contents, it was found that the pretest and the posttest were not correlated with each other $(\mathrm{Sig} .=0.000)$, as the negative values had the opposite direction of correlation $(\mathrm{r}=0.760)$, and the post-test scores had a higher level than the pretest with a statistical significance level of .05.

The concluding assessment result of the creation of the three-dimensional images was involved with the integration of learning between active learning and childcentered learning for the student groups. Additionally, it was found that all five components of learning in the classrooms of the pretest and the post-test were correlated $(\mathrm{Sig} .=0.000)$, as the positive value in the same direction of correlation $(r=0.492)$. In this case, the score test for the post-test was at a higher level than the pretest and had a statistical significance level of .05.

\section{Discussion and Conclusion}

From the positive features for active learning with the creation of threedimensional images of the designed product work by the student groups, this could be presented as eight components: 1) Beauty emphasizing the practicing of the images communication skills, 2) suitable eye view, 3) creation of suitable illusion images, 4) knowledge principle and theory, 5) learning atmosphere in the classroom, 6) intellectual field to be available for high effective knowledge, 7) feeling confident with the knowledge in the classroom, and 8) feeling of independent learning that was congruent with the learning pattern of active learning. Thus, according to the high effectiveness from the active learning practice, this had the trend to promote empirical learning that was congruent with the learners' behavior by being expressed with the increasing intelligence during the participation of the learning activities in the classroom [35-36].

From the positive features for child-centered learning with the creation of the three-dimensional images of the designed product work of the student groups, these features consisted of three components: 1) Imagination, 2) active learning skills of creative modeling, and 3) feeling of amusement with learning that was congruent with the learning pattern of child-centered learning. This applied documents and a variety of textbooks to promote learning that resulted in the development of high intelligence 
for the learners. In this case, this was able to develop the independence skills and learning acceptance by oneself in the relevant ways [37-38].

The integration of the two learning patterns was able to be fulfilled as suitable learning with the three-dimensional image goals in designing the product work [39]. Thus, according to the results, this showed that the pretest and post-test scores for the student groups had correlation in positive ways that were in the same direction of correlation, including the post-test score result that gained a higher level than the pretest score with a statistical significance level of .05. Additionally, this was in accordance with the requirement of the concepts with the examination of the two-sides intellectual skills based on knowledge participation and assistance skills between the learners and the instructors. With this case, this demonstrated a positive trend to gain a better result of teaching successively, including the learning process with integration in multiple learning units contributing to better performance [40]. In contrast, provided that there was assistance from the classmates, this would make the learning stimulation gain the development of the social dimension and relationships until becoming a creative learning strength [41].

By directly applying one learning type with the same learning pattern, this contributed to eliminating some parts of the intellectual skills and craft skills. Furthermore, this directly affected the learning effectiveness of the three-dimensional images for the students, including the learners who were not prepared in the long term for practicing designing work after graduation [42-43]. Therefore, provided that the instructors applied an integration of the learning patterns of active learning and childcentered learning, this would fully generate the perfection to level up the knowledge and craft skills for the learners, including create interest with high effectiveness. Finally, according to the results for the student groups, this confirmed that the ideas had an increasing trend of generating better scores with the students after applying these two learning patterns simultaneously; the better result from the learners showed the additional skills [44]; such as, good thinking skill and flexible thinking skill after graduation from the classrooms [45-46].

\section{Acknowledgement}

This research received a grant from the budget of the Faculty of Industrial Education and Technology, King Mongkut's Institute of Technology Ladkrabang, Thailand.

\section{$6 \quad$ References}

[1] Kelsey Hood Cattaneo. (2017). Telling Active Learning Pedagogies Apart: from theory to practice. Journal of New Approaches in Educational Research, 6(2): 144-152. https://doi. org/10.7821/naer.2017.7.237

[2] Vasfi Tugun, Almira R. Bayanova, Klavdiya G. Erdyneeva, Nikolay A. Mashkin, Zavgaria M. Sakhipova \& Liubov V. Zasova. (2020). The Opinions of Technology Supported Education of University Students. International Journal of Emerging Technologies in Learning, 15(23): 4-14. https://doi.org/10.3991/ijet.v15i23.18779 
[3] Youngblood, Nancy \& Beitz, Janice M. (2001). Developing Critical Thinking with Active Learning Strategies. Nurse Educator, 26(1): 39-42. https://doi.org/10.1097/00006223200101000-00016

[4] Tedesco-Schneck, Mary. (2013). Active learning as a path to critical thinking: Are competencies a roadblock? Nurse Education in Practice, 13(1): 58-60. https://doi.org/ $\underline{10.1016 / j . n e p r .2012 .07 .007}$

[5] Petress, Ken. (2008). What is Meant by “Active Learning?”. Education, 128(4): 566-569.

[6] Yaqun Zhang, Fayruza Rebrina, Fairuza Sabirova \& Julia Afanaseva. (2020). Blended Learning Environments in Inclusive Education at the University. International Journal of Emerging Technologies in Learning, 15(21): 145-161. https://doi.org/10.3991/ijet.v15i21. $\underline{16013}$

[7] Cheung, Sum Kwing., Fong, Ricci Wai-tsz., Leung, Suzannie Kit Ying. \& Ling, Elsa Kawei. (2019). The Roles of Hong Kong Preservice Early Childhood Teachers' Creativity and Zest in Their Self-efficacy in Creating Child-centered Learning Environments. Early Education and Development, 30(6): 788-799. https://doi.org/10.1080/10409289.2019.1586 $\underline{224}$

[8] Keyser, Marcia. (2000). Active learning and cooperative learning: understanding the difference and using both styles effectively. Research Strategies, 17(1): 35-44. https://doi. org/10.1016/s0734-3310(00)00022-7

[9] Clark, Douglas B., Nelson, Brian C., Chang, Hsin-Yi, Martinez-Garza, Mario., Slack, Kent \& D'Angelo, Cynthia M. (2011). Exploring Newtonian mechanics in a conceptuallyintegrated digital game: Comparison of learning and affective outcomes for students in Taiwan and the United States. Computers \& Education, 57(3): 2178-2159. https://doi. org/10.1016/j.compedu.2011.05.007

[10] Säljö, Roger. (1979). Learning about learning. Higher Education, 8(4): 443-451. https: //doi.org/10.1007/BF01680533Wallace, Benjamin., (1984). Creation of the horizontalvertical illusion through imagesry, Bulletin of the Psychonomic Society, 22(1), 9-11. https://doi.org/10.3758/bf03333746

[11] Sanders, Elizabeth B.-N. \& Stappers, Pieter Jan. (2008). Co-creation and the new landscapes of design, CoDesign, 4(1), 5-18. https://doi.org/10.1080/15710880701875068

[12] Geus, Sjanett De, Richards, Greg \& Toepoel, Vera. (2016). Conceptualisation and Operationalisation of Event and Festival Experiences: Creation of an Event Experience Scale, Scandinavian Journal of Hospitality and Tourism, 16(3), 274-296. https://doi.org/ $\underline{10.1080 / 15022250.2015 .1101933}$

[13] Robert I.Sutton \& Andrew Hargadon. (1996). Brainstorming Groups in Context: Effectiveness in a Product Design Firm, Administrative Science Quarterly, 41(4), 685-718. https://doi.org/10.2307/2393872

[14] Matthews, Ben. (2009). Intersections of brainstorming rules and social order, CoDesign, 5(1), 65-76. https://doi.org/10.1080/15710880802522403

[15] Kamins, M. L., \& Dweck, C. S. (1999). Person versus process praise and criticism: Implications for contingent self-worth and coping. Developmental Psychology, 35(3), 835-847. https://doi.org/10.1037/0012-1649.35.3.835

[16] John H. Elliot. (2011). Social-scientific criticism: Perspective, process and payoff. Evil eye accusation at Galatia as illustration of the method, Original Research, 67(1), 1-10. https://doi.org/10.4102/hts.v67i1.858

[17] Konkova, E., MacFarlane, A. \& Goker, G. (2016). Analysing Creative Images Search Information Needs. Knowledge Organization: international journal devoted to concept theory, classification, indexing, and knowledge representation, 43(1), 13-21. https://doi. org/10.5771/0943-7444-2016-1-13 
[18] Falomir, Zoe \& Plaza, Enric. (2020). Towards a model of creative understanding: deconstructing and recreating conceptual blends using images schemas and qualitative spatial descriptors. Annals of Mathematics and Artificial Intelligence, 88(5), 457-477. https://doi.org/10.1007/s10472-019-09619-9

[19] Somers, J. U., \& Yawkey, T. D. (1984). Imaginary play companions: Contributions of creative and intellectual abilities of young children. The Journal of Creative Behavior, 18(2), 77-89. https://doi.org/10.1002/j.2162-6057.1984.tb00370.x

[20] Tomlinson-Keasey, C. (1990). Developing our intellectual resources for the 21st century: Educating the gifted. Journal of Educational Psychology, 82(3), 399-403. https://doi. org $/ 10.1037 / \mathrm{h} 0092680$

[21] Jamil Salmi. (2001). Tertiary Education in the 21st Century: Challenges and Opportunities. Higher Education Management, 13(2), 105-128.

[22] Davies, Martin. (2011). Concept mapping, mind mapping and argument mapping: what are the differences and do they matter? Higher Education, 62(3), 279-301. https://doi.org/ $10.1007 / \mathrm{s} 10734-010-9387-6$

[23] Crowe, Michael. (2012). Mind mapping research methods. Quality \& Quantity, 46(5), 1493-1504. https://doi.org/10.1007/s11135-011-9463-8

[24] Eliot, T. (1956). The Frontiers of Criticism. The Sewanee Review, 64(4), 525-543. Retrieved December 23, 2020, from http://www.jstor.org/stable/27538564

[25] Monroe C. Beardsley. (1965). On the Creation of Art. The Journal of Aesthetics and Art Criticism, 23(3), 291-304. https://doi.org/10.1111/1540 6245.jaac23.3.0291

[26] Robert J. Sternberg \& Todd I. Lubart. (1991). Creating Creative Minds. The Phi Delta Kappan, 72(8), 608-614. https://www.jstor.org/stable/20404480

[27] Richard M. Felder. (1987). On Creating Creative Engineers. Engineering Education, 77(4), 222-227.

[28] Voorberg, W. H., Bekkers, V. J. J. M. \& Tummers, L. G. (2015). A Systematic Review of Co-Creation and Co-Production: Embarking on the social innovation journey. Public Management Review, 17(9), 1333-1357. https://doi.org/10.1080/14719037.2014.930505

[29] Dollinger, Mollie., Lodge, Jason \& Coates, Hamish. (2018). Co-creation in higher education: towards a conceptual model. Journal of Marketing for Higher Education, 28(2), 210231. https://doi.org/10.1080/08841241.2018.1466756

[30] Perkins D. \& Salomon G. (1989). Are Cognitive Skills Context-Bound? Educational Researcher, 18(1), 16-25. doi:10.3102/0013189X018001016

[31] Royer, James M., Cisero, Cheryl A. \& Carlo, Maria S. (1993). Techniques and Procedures for Assessing Cognitive Skills. Review of Educational Research, 63(2), 201-243. https:// doi.org/10.3102/00346543063002201

[32] Cheung, Sum Kwing., Fong, Ricci Wai-tsz., Leung, Suzannie Kit Ying \& Ling, Elsa Kawei. (2019). The Roles of Hong Kong Preservice Early Childhood Teachers' Creativity and Zest in Their Self-efficacy in Creating Child-centered Learning Environments. Early Education and Development, 30(6), 788-799. https://doi.org/10.1080/10409289.2019.158 $\underline{6224}$

[33] Pereira, Jennifer K. \& Smith-Adcock, Sondra. (2011). Child-Centered Classrooms Management. Action in Teacher Education, 33(3), 254-264. https://doi.org/10.1080/01626620. 2011.592111

[34] Yoder, Janice D. \& Hochevar, Catherine M. (2005). Encouraging Active Learning Can Improve Students' Performance on Examinations. Teaching of Psychology, 32(2), 91-95. https://doi.org/10.1207/s15328023top3202_2 
[35] Chi, Michelene T. H. \& Wylie, Ruth. (2014). The ICAP Framework: Linking Cognitive Engagement to Active Learning Outcomes. Educational Psychologist, 49(4), 219-243. https://doi.org/10.1080/00461520.2014.965823

[36] Fung, Chanel Kit Ho. (2015). "Active Child" and "Active Teacher": Complementary Roles in Sustaining Child-centered Curriculum. Childhood Education, 91(6), 420-431. https://doi.org/10.1080/00094056.2015.1114787

[37] Lerkkanen, Marja-Kristiina., et al, (2016). Child-centered versus teacher-directed teaching practices: Associations with the development of academic skills in the first grade at school. Early Childhood Research Quarterly, 36(1), 145-156. https://doi.org/10.1016/j.ecresq.20 $\underline{15.12 .023}$

[38] Pakarinen, Eija \& Kikas, Eve. (2019). Child-centered and teacher-directed practices in relation to calculation and word problem solving skills. Learning and Individual Differences, 70(1), 70-76. https://doi.org/10.1016/j.lindif.2019.01.008

[39] Borte, Kristin., Nesje, Katrine \& Lillejord, Solvi. (2020). Barriers to student active learning in higher education. Teaching in Higher Education, 1-19. https://doi.org/10.1080/1356 2517.2020.1839746

[40] Matthews, Mona W. (1996). Addressing issues of peer rejection in child-centered classrooms. Early Childhood Education Journal, 24(2), 93-97. https://doi.org/10.1007/bf023 $\underline{53287}$

[41] Yu Gao. (2020). Blended Teaching Strategies for Art Design Major Courses in Colleges. International Journal of Emerging Technologies in Learning, 15(24), 145-158. https:// doi.org/10.3991/ijet.v15i24.19033

[42] Miriam Mulders, Josef Buchner \& Michael Kerres. 2020. A Framework for the Use of Immersive Virtual Reality in Learning Environments. International Journal of Emerging Technologies in Learning, 15(24), 208-224. https://doi.org/10.3991/ijet.v15i24.16615

[43] Guilford, J. P. (1957). Creative abilities in the arts. Psychological Review, 64(2), 110-118. https://doi.org/10.1037/h0048280

[44] Chengchun Shen \& Aili Qi. (2020). An Adaptive Learning Mode of "Public Psychology" Based on Creative Thinking with Virtual Simulation Technology. International Journal of Emerging Technologies in Learning, 15(23), 131-144. https://doi.org/10.3991/ijet.v15i23. $\underline{18957}$

[45] Jing Peng. (2020). Intelligent Technology-Based Improvement of Teaching Ability of Professional Courses in Art Design. International Journal of Emerging Technologies in Learning, 15(23), 131-144. 193-207. https://doi.org/10.3991/ijet.v15i23.19029

\section{Authors}

Songwut Egwutvongsa is an instructor in the field of product design. Associate Professor of the Department of Architectural Education and Design, King Mongkut's Institute of Technology Ladkrabang, Bangkok, Thailand, ORCID id: 0000-00028443-3975, Songwut.ae@kmitl.ac.th / momojojo108@gmail.com

Somchai Seviset is an instructor in the field of product design. Assistant professor of the Department of Architectural Education and Design, King Mongkut's Institute of Technology Ladkrabang, Bangkok, Thailand, ORCID id: 0000-0002-3909-0387, kssomcha@yahoo.com

Article submitted 2021-01-28. Resubmitted 2021-02-26. Final acceptance 2021-02-26. Final version published as submitted by the authors. 